\title{
Evaluation of Cytoskeleton-Linking Membrane Protein 63 as a Serum Marker for the Early Detection of Hepatocellular Carcinoma
}

\author{
ALI A. YOUSEF, M.Sc.*; MEDHAT A. GHAZY, M.D.*; FAYZA I. LASHEN, M.D.* and \\ MAALY M. MABROUK, M.D.** \\ The Departments of Internal Medicine* and Clinical Pathology**, Faculty of Medicine, Tanta University
}

\begin{abstract}
Background: Hepatocellular Carcinoma (HCC) is the third most common cause of cancer death worldwide. The burden of HCC has been increasing in Egypt with a doubling in the incidence rate in the past ten years. Subsequently, novel serum markers are needed to improve the diagnostic accuracy of HCC especially with the low sensitivity of a-Fetoprotein (AFP).
\end{abstract}

Aim of Study: Evaluation of serum Cytoskeleton Linking Membrane Protein-63 (CLIMP-63) as a marker for diagnosis of HCC.

Patients and Methods: Eighty individuals were included and they were divided into three groups (30 HCC patients, 30 cirrhotic patients and 20 healthy individuals). Samples were collected and serum CLIMP-63 was determined with Enzyme-Linked Immunosorbent Assays (ELISA). The area under the Receiver Operating Characteristic curve (AuROC), sensitivity and specificity of AFP and CLIMP-63 levels were evaluated for diagnostic performance.

Results: Serum CLIMP-63 levels in HCC patients were much higher than healthy individuals and cirrhotic patients ( $p$-value $=0.001)$. The AuROC, sensitivity and specificity of serum CLIMP-63 for the diagnosis of HCC were $0.782,80 \%$ and $68 \%$, respectively. The AuROC, sensitivity and specificity of AFP for the diagnosis of HCC were $0.712,75 \%$ and $70 \%$, respectively.

Conclusions: Serum CLIMP-63 may be a novel serum biomarker for diagnosis of HCC in the early stage and testing serum CLIMP-63 and AFP may improve the detection rate of HCC.

Key Words: HCC - Tumor markers - Cytoskeleton linking membrane protein-63.

\section{Introduction}

HCC has become the commonest solid tumor all over the world and the third leading cause of tumor-

Correspondence to: Dr. Ali Abd El-Fattah Yousef, The Department of Internal Medicine, Faculty of Medicine, Tanta University related mortality in many countries [1]. The prognosis of HCC patients is generally very poor with a 5-year survival rate of less than $10-15 \%$ owing to deficiency of effective and timely diagnostic methods [2].

AFP is an important marker for diagnosis of HCC. AFP is very useful if it is markedly increased [3] . Furthermore, the specificity of AFP is low because serum levels of AFP are increased in many patients with hepatitis, cirrhosis and gastrointestinal cancers [4].

Cytoskeleton Linking Membrane Protein-63 (CLIMP-63), also known as p63, CKAP4, and ERGIC-63, is a $63-\mathrm{kDa}$ nonglycosylated, type II transmembrane protein located in the endoplasmic reticulum $[5,6]$. CLIMP-63 is strongly related to the tumor growth, proliferation, invasion, and metastasis [7].

Based on the previous studies of CLIMP-63 in tumors, we aimed to evaluate whether serum CLIMP-63 can be used as a biomarker in the detection of HCC.

\section{Subjects and Methods}

This cross-sectional study was carried out on sixty patients were recruited at outpatient clinic and ICU patients, admitted to Internal Medicine Department at Tanta University Hospital from November 2016 to April 2017. The study also included twenty individuals as a control group.

All participants provided informed written consent and the study was approved by Tanta Faculty of Medicine Ethical Committee. Patients with previous treatment for $\mathrm{HCC}$ and patients with other malignancies are excluded from the study. 
The subjects were divided into 3 groups: Group I included 30 patients with HCC, Group II included 30 patients with cirrhosis and Group III included 20 healthy individuals of matched age and sex as a control group.

They were subjected to complete history taking including age, sex, residence, occupation, history of hepatic encephalopathy and history of previous intervention for HCC (HCC patients). Full clinical examination, with special emphasis on stigmata of chronic liver disease (ascites, jaundice, limb edema, etc.). Laboratory investigations including Complete Blood Count (CBC), viral markers (HCV $\mathrm{Ab}$ and $\mathrm{HBs} \mathrm{Ag}$ ), liver function tests (ALT, AST, serum albumin, serum bilirubin, prothrombin time, activity and INR), blood urea and serum creatinine, serum AFP and serum CLIMP-63 by ELISA. Radiological investigations including abdominal ultrasound and triphasic CT abdomen.

All samples were taken under complete aseptic measures. Eight $\mathrm{ml}$ of venous blood samples from antecubital vein were withdrawn under complete aseptic technique and were divided into; $2 \mathrm{ml}$ was added to a tube containing EDTA for CBC; $1.8 \mathrm{ml}$ was added for a tube containing $0.2 \mathrm{ml}$ sodium citrate for prothrombin time estimation and the rest of withdrawn sample was put into a plain tube for serum preparation.

The serum was divided into two aliquots; one aliquot used for liver, renal, viral markers and AFP estimation, and the other aliquot was stored at $-20^{\circ} \mathrm{C}$ under the manufacture instructions for serum
CLIMP-63 determination. Serum CLIMP-63 was done by Human CLIMP-63 ELISA kit (Sun Red) (catalogue No. 201-12-7345).

\section{Statistical analysis:}

Statistical presentation and analysis of the present study was conducted, using the mean, standard deviation, chi-square test, $t$-test, f-test, Linear Correlation Coefficient and ROC-curve by SPSS V.20.

Receiver Operating Characteristic (ROC) curves for serum CLIMP-63 and AFP were constructed, to assess their diagnostic accuracy in distinguishing HCC patients from normal control subjects.

\section{Results}

The characteristics of the studied groups as regard demographic data (age \& sex), tumor markers (AFP \& CLIMP-63) and virology are shown in (Table 1).

There was no statistical significance between the studied groups as regard age and sex $p$-value $0.501,0.434$ respectively (Table 1 ). Our results also showed that comparison between HCC group and cirrhosis group as regard virology was statistically non-significant ( $p$-value 0.278) (Table 1).

Our results also showed that there was significant increase in AFP and CLIMP-63 levels in HCC group as compared with control and cirrhosis groups with $p$-value 0.043 and 0.001 respectively (Table 1).

Table (1): Comparison between the studied groups as regard demographic data, tumor markers and virology.

\begin{tabular}{|c|c|c|c|c|}
\hline & $\begin{array}{l}\mathrm{HCC} \\
\mathrm{N}=30\end{array}$ & $\begin{array}{c}\text { Cirrhosis } \\
\mathrm{N}=30\end{array}$ & $\begin{array}{c}\text { Control } \\
\mathrm{N}=20\end{array}$ & $\begin{array}{c}p- \\
\text { value }\end{array}$ \\
\hline $\begin{array}{l}\text { Sex: } \\
\text { - Male } \\
\text { - Female }\end{array}$ & $\begin{array}{l}17 \\
13\end{array}$ & $\begin{array}{l}17 \\
13\end{array}$ & $\begin{array}{l}8 \\
12\end{array}$ & 0.434 \\
\hline $\begin{array}{l}\text { Age: } \\
\text { - Mean } \pm \text { S.D. }\end{array}$ & $56.20 \pm 5.89$ & $55.67 \pm 9.44$ & $53.70 \pm 6.41$ & 0.501 \\
\hline $\begin{array}{l}\text { Virology: } \\
\text { - HCVAb +ve } \\
\text { - HBsAg + ve } \\
\text { - HCVAb \& HBsAg - ve }\end{array}$ & $\begin{array}{l}27 \\
0 \\
3\end{array}$ & $\begin{array}{l}24 \\
0 \\
6\end{array}$ & $\begin{array}{l}0 \\
0 \\
20\end{array}$ & 0.278 \\
\hline $\operatorname{AFP}(n g / m l)$ & $51.64 \pm 134.4$ & $6.16 \pm 7.83$ & $3.08 \pm 1.81$ & $\begin{array}{rl}0.043^{*} & p_{1} 0.036^{*} \\
p_{2} & 0.042^{*} \\
p_{3} & 0.868\end{array}$ \\
\hline CLIMP-63 (ng/ml) & $2.61 \pm 2.75$ & $1.13 \pm 0.60$ & $0.44 \pm 0.27$ & $\begin{array}{rl}0.001 * & p_{1} 0.001 * \\
p_{2} & 0.001 * \\
p_{3} & 0.167\end{array}$ \\
\hline
\end{tabular}


Table (2): Correlation between AFP and CLIMP with Child Pugh and MELD scores in HCC group.

\begin{tabular}{lcccc}
\hline \multirow{2}{*}{ HCC } & \multicolumn{2}{c}{ CLIMP-63 } & \multicolumn{2}{c}{ AFP } \\
\cline { 2 - 5 } & $\mathrm{r}$. & $\mathrm{p}$ & $\mathrm{r}$. & $\mathrm{p}$ \\
\hline MELD & -0.004 & 0.983 & -0.069 & 0.715 \\
Child Pugh score & 0.333 & 0.072 & 0.032 & 0.867 \\
\hline
\end{tabular}

*: Significant $p$-value $<0.05$.

Table (3): Correlation between CLIMP-63 with Portal Vein Thrombosis (PVT), number of focal lesions and tumor size in HCC group.

\begin{tabular}{lcccc}
\hline Patients & \multicolumn{4}{c}{ CLIMP-63 } \\
\hline Parameter & No. & $\%$ & $r$. & $p$ \\
\hline $\begin{array}{l}\text { Portal vein thrombosis: } \\
\text { - Present }\end{array}$ & 14 & 46.7 & -0.312 & 0.093 \\
- Absent & 16 & 53.3 & & \\
Number of focal lesions: & & & & \\
- Single & 22 & 73.3 & 0.015 & 0.936 \\
- Double & 4 & 13.3 & & \\
- Multiple & 4 & 13.3 & & \\
Tumor size: & & & & \\
$\bullet<-5 \mathrm{~cm}$ & 20 & 66.7 & 0.434 & $0.017^{*}$ \\
- $>5 \mathrm{~cm}$ & 10 & 33.3 & & \\
\hline
\end{tabular}

*: Significant $p$-value $<0.05$.
Table (2) showed that correlation between AFP and CLIMP-63 with Child Pugh and MELD scores in $\mathrm{HCC}$ group was statistically non-significant.

Table (3) showed the characteristics of HCC group as regard PVT, number of focal lesions and tumor size. It also showed that there was no statistically significant correlation between CLIMP-63 with PVT and number of focal lesions, but there was statistically significant positive correlation between CLIMP-63 and tumor size ( $p$-value $=0.017$ ) Fig. (1).

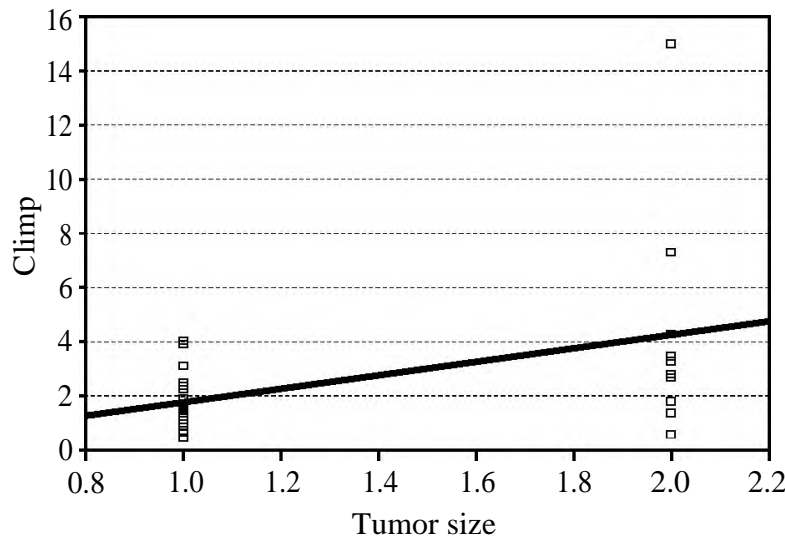

Fig. (1): Correlation between CLIMP-63 with tumor size.

Table (4): AFP and CLIMP-63 specificity and sensitivity for HCC diagnosis.

\begin{tabular}{lccccccc}
\hline HCC & AUC & Cutoff & Sensitivity & Specifivity & PPV & NPV & Accuracy \\
\hline AFP & 0.712 & $>5 \mathrm{ng} / \mathrm{ml}$ & 75 & 70 & 72 & 80 & 75 \\
CLIMP-63 & 0.782 & $>0.5 \mathrm{ng} / \mathrm{ml}$ & 80 & 68 & 77 & 68 & 75 \\
\hline
\end{tabular}

Considering a cut off value of $5 \mathrm{ng} / \mathrm{ml}$ for AFP: It shows $75 \%$ sensitivity and $70 \%$ specificity for HCC diagnosis with area under the curve 0.712 (Table 4) Fig. (2A).

Considering a cut off value of $0.5 \mathrm{ng} / \mathrm{ml}$ for CLIMP-63: It shows $80 \%$ sensitivity and $68 \%$

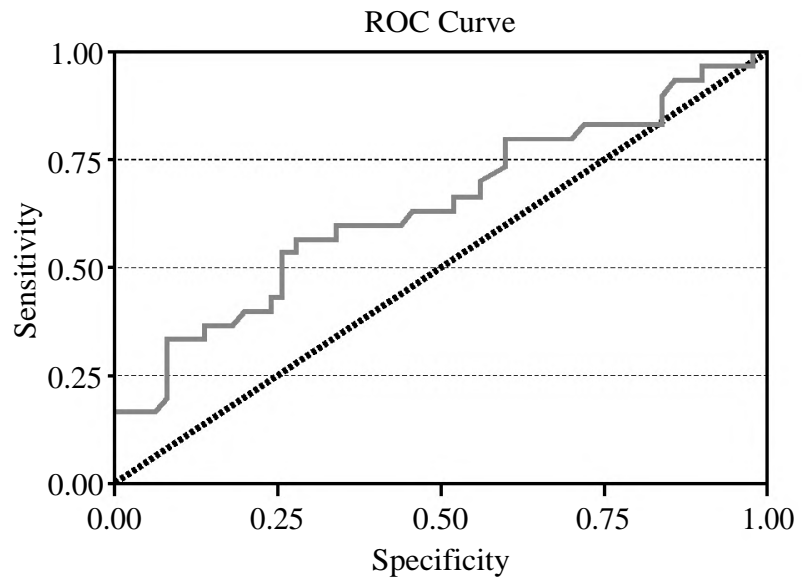

Fig. (2A): AFP specificity and sensitivity. specificity for HCC diagnosis with area under the curve 0.782 (Table 4) Fig. (2B).

Table (5) shows that there is significant increase in serum CLIMP-63 in HCC patients with AFP $<10 \mathrm{ng} / \mathrm{ml}$ as compared with control group ( $p$-value $=0.001$ ).

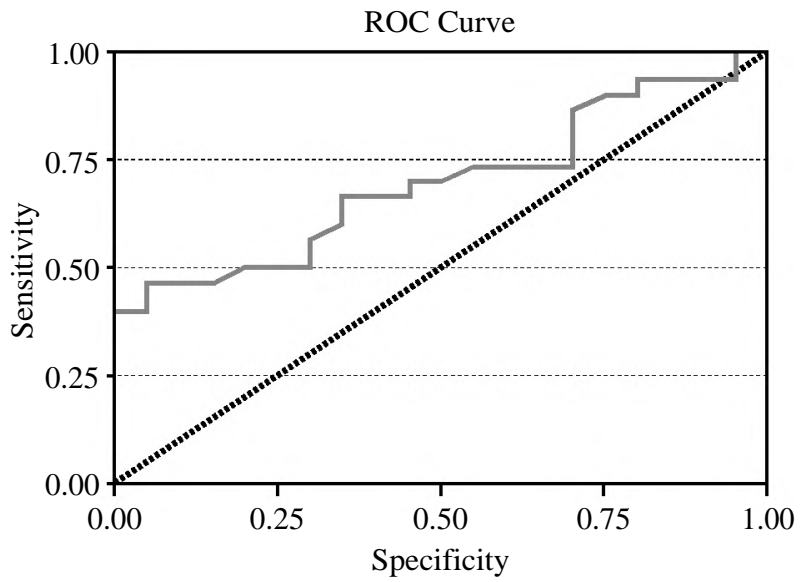

Fig. (2B): CLIMP-63 specificity and sensitivity. 
Table (5): CLIMP-63 in HCC patients with AFP $<10 \mathrm{ng} / \mathrm{ml}$ as compared with control group.

\begin{tabular}{|c|c|c|c|c|}
\hline CLIMP-63 & Range & Mean $\pm \mathrm{SD}$ & F-test & $p$-value \\
\hline Control & $0.1-1.3$ & $0.44 \pm 0.27$ & 7.408 & $0.001 * p_{1} 0.036 *$ \\
\hline $\mathrm{HCC}$ with AFP <10ng/ml & $0.6-15$ & $2.99 \pm 2.13$ & & $p_{2} 0.042^{*}$ \\
\hline $\mathrm{HCC}$ with AFP $>10 \mathrm{ng} / \mathrm{ml}$ & $0.4-4.3$ & $1.73 \pm 0.58$ & & $p_{3} 0.868$ \\
\hline
\end{tabular}

\section{Discussion}

HCC is the sixth most common cancer in the world [8]. Prognosis of HCC is poor since $\mathrm{HCC}$ can be mostly diagnosed at an advantaged stage. Over the past few decades, it has drawn attention worldwide to screen for an early diagnosis of $\mathrm{HCC}[8]$

However, the limitation of AFP from the low sensitivity as the major serum marker for diagnosis of HCC in clinical practice, reliable and novel markers is urgently needed to improve the diagnostic accuracy for HCC $[\mathbf{9 , 1 0}]$.

CLIMP-63 is strongly related to the tumor growth, proliferation, invasion, and metastasis [7] Expression of CLIMP-63 is significantly associated with tumor size, lymph node metastasis, and TNM stage features and is a prognostic marker in patients with intrahepatic cholangiocarcinoma [9] .

In addition, CLIMP-63 can inhibit tumor intrahepatic metastasis and venous invasion, and is a prognostic marker in patients with HCC [10]. Previous studies of CLIMP-63 in tumors made CLIMP-63 an attractive target as a tumor biomarker.

We had the opportunity to evaluate serum CLIMP-63 in the three groups and correlate it with Child-Pugh score and MELD score. We also compared it with AFP level and compared between AFP and CLIMP-63 in the sensitivity and specificity for HCC diagnosis.

In this study, serum CLIMP-63 levels were significantly increased in patients with HCC, as compared to individuals without cancer (healthy and cirrhosis groups).

Shuangxi Li, et al. [8] agreed with this and also demonstrated that serum CLIMP-63 levels were sequentially increased in HCC according to progression of disease based on the theory of heptocarcinogenesis (hepatitis-cirrhosis-carcinoma sequence).
A study done by Shuang-Xi Li, et al. [10] on hepatic tissue taken by liver biopsy from HCC patients and liver hemangioma patients as normal controls showed that large numbers of HCC patients had high expression of CLIMP-63 in tumor tissues as compared with control group.

Our study showed that the sensitivity and specificity of serum CLIMP-63 for the diagnosis of HCC were $80 \%$ and $68 \%$, respectively. For AFP, the sensitivity and specificity were $75 \%$ and $70 \%$, respectively.

Shuangxi Li, et al. [8] reported that the sensitivity and specificity of serum CLIMP-63 for the diagnosis of $\mathrm{HCC}$ were $76.2 \%$ and $65.7 \%$, respectively. For AFP, the sensitivity and specificity were $66.7 \%$ and $60 \%$, respectively.

Our study showed that there was significant increase in serum CLIMP-63 in HCC patients with AFP cut off value less than $10 \mathrm{ng} / \mathrm{ml}$ as compared with control group and this data indicated that estimation of serum CLIMP-63 could increase the diagnostic efficacy when AFP is low or negative and could help in the early detection of HCC.

Shuangxi Li, et al. [8] demonstrated that serum CLIMP-63 increased in HCC patient with AFP cut off value less than $20 \mathrm{ng} / \mathrm{ml}$. It also showed that the sensitivity and specificity of CLIMP-63 were better in HCC detection when the AFP cut off value less than $20 \mathrm{ng} / \mathrm{ml}$.

Our study showed that there was significant positive correlation between serum CLIMP-63 and tumor size. The study done by Shuang-Xi Li, et al. [10] demonstrated that expression of CLIMP63 in hepatic tissue of HCC patients had significant positive correlation with tumor size.

Our study showed that there was no significant correlation between serum CLIMP-63 with Portal Vein Thrombosis (PVT) and number of focal lesions. 
Shuang-Xi Li, et al. [10] reported that there was no significant correlation between expression of CLIMP-63 in hepatic tissue of HCC patients and number of focal lesions, but it shows that there was a positive correlation between expression of CLIMP-63 and PVT.

The study done by Shuang-Xi Li, et al. [10] also reported that there was a significant positive correlation between expression of CLIMP-63 in hepatic tissue of HCC patients with TNM and BCLC staging systems.

The study done by Shuang-Xi Li, et al. [10] also showed that there was no significant correlation between expression of CLIMP-63 in hepatic tissue of HCC patients and distant metastasis and it also reported that there was no significant correlation between expression of CLIMP-63 in hepatic tissue of HCC patients and presence or absence of cirrhosis.

In this study, there was relatively small sample size and there were small available researches about CLIMP-63 especially its relation to HCC.

\section{Conclusion:}

CLIMP-63 may be a novel serum marker for diagnosis of HCC in the early stage and testing serum CLIMP-63 and AFP may improve the detection rate of $\mathrm{HCC}$.

\section{Recommendations:}

Serum CLIMP-63 may be used with AFP for early detection of $\mathrm{HCC}$ and further studies with larger sample size from different stage of HCC may be needed to confirm and validate CLIMP63 as a diagnostic marker.

\section{Acknowledgements:}

We would like to thank all participants who helped during this study.

\section{Conflict of interest:}

None declared.

\section{References}

1- LAFARO K.J., DEMIRJIAN A.N. and PAWLIK T.M.: Epidemiology of hepatocellular carcinoma. Surgical Oncology Clinics, 24 (1): 1-17, 2015.

2- KAWANO Y., SASAKI A., KAI S., ENDO Y., IWAKI K., UCHIDA H., et al.: Short-and long-term outcomes after hepatic resection for hepatocellular carcinoma with concomitant esophageal varices in patients with cirrhosis. Annals of surgical oncology, 15 (6): 1670-6, 2008.

3- SCHWARTZ J.M., CARITHERS R.L., CHOPRA S., TRAVIS A.C. and SAVARESE D.M.F.: Clinical features and diagnosis of primary hepatocellular carcinoma. UpToDate Inc., 2015.

4- SPANGENBERG H.C., THIMME R. and BLUM H.E.: Serum markers of hepatocellular carcinoma. In Seminars in liver disease (Vol. 26, No. 04, pp. 385-90), 2006.

5- GUPTA N., MANEVICH Y., KAZI A.S., TAO J.Q., FISHER A.B. and BATES S.R.: Identification and characterization of p63 (CKAP4/ERGIC-63/CLIMP-63), a surfactant protein A binding protein, on type II pneumocytes. American Journal of Physiology-Lung Cellular and Molecular Physiology, 291 (3): L436-L46, 2006.

6- TUFFY K.M. and PLANEY S.L.: Cytoskeleton-associated protein 4: Functions beyond the endoplasmic reticulum in physiology and disease. ISRN Cell Biology, 2012.

7- CONRADS T.P., TOCCI G.M., HOOD B.L., ZHANG C.O., GUO L., KOCH K.R., et al.: CKAP4/p63 is a receptor for the frizzled-8 protein-related antiproliferative factor from interstitial cystitis patients. Journal of Biological Chemistry, 281 (49): 37836-43, 2006.

8- LI S., WANG H., FAN J., WANG C., DONG L., ZHONG Z., et al.: Cytoskeleton-Linking Membrane Protein 63 as a serum biomarker for the early detection of hepatocellular carcinoma. International Journal of Clinical and Experimental Pathology, 9 (2): 1720-6, 2016.

9- LI M.H., DONG L.W., LI S.X., TANG G.S., PAN Y.F. ZHANG J., et al.: Expression of cytoskeleton-associated protein 4 is related to lymphatic metastasis and indicates prognosis of intrahepatic cholangiocarcinoma patients after surgery resection. Cancer letters, 337 (2): 248-53, 2013.

10- LI S.X., TANG G.S., ZHOU D.X., PAN Y.F., TAN Y.X. ZHANG J., et al.: Prognostic significance of cytoskeletonassociated membrane protein 4 and its palmitoyl acyltransferase DHHC2 in hepatocellular carcinoma. Cancer, 120 (10): 1520-31, 2014. 


\section{تقييه بروتين با المتصل بغشاء الهيكل الخلوى كدلالة مصلية للكشف المبكر عن سرطان الكبد الميد الميك}

آصبح سرطان الذلايا الكبدية الآكثر شيوعا بين الآودام الصلبة فى جميع آنحاء العالم وثيالث سبب رئيسى للوفاة بين حالات الوفاة المتعلقة

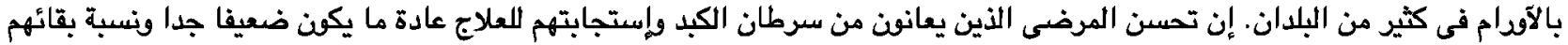

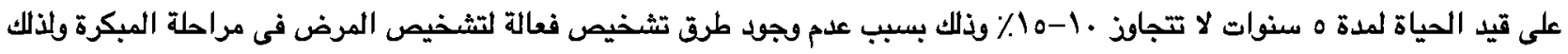

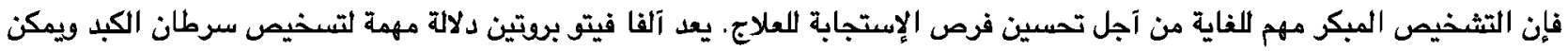

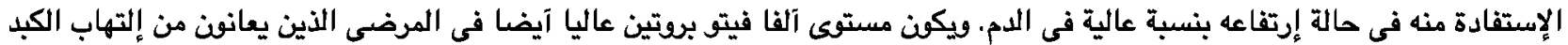

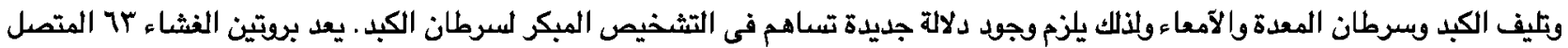

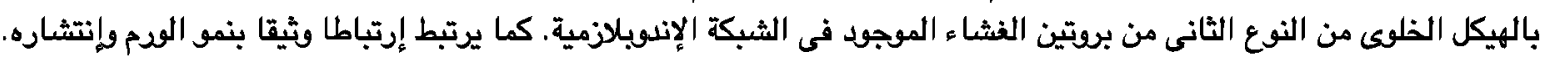

الهدف من البحث: تهدف هذه الدراسة إلى تقييم مستوى مصل بروتين الغشاء rا المتصل بالهيكل الخلوى فى مرضى سرطان الكبد

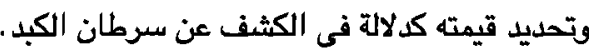

البحث: لقد آجريت هذه الدراسة على ثمانين شخصا فى قسم الآمراض الباطنة بمستشفى جامعة طنطا وتم تقسيمهم إلى ثلاث مجموعات:

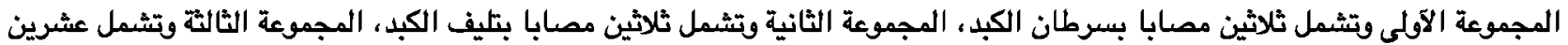

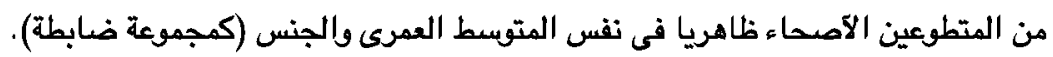

وقد تم إجراء الآتى: التاريخ المرضى الكامل والفحص الإكينيكى الشامل والفحوصات المعملية وتشمل: صورة دم كاملة ودلالات فيروسات

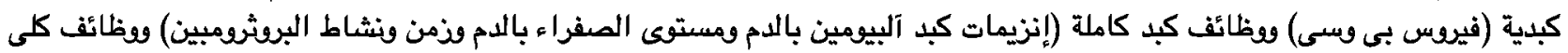

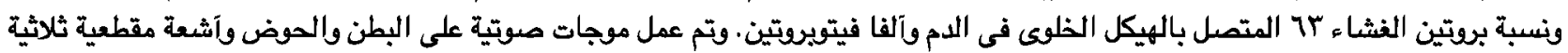

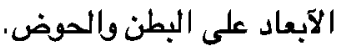

النتائج: لقد آظهرت التتائج آن مستوى بروتين الغشاء باج المتصل بالهيكل الخلوى يزيد فى حالات التليف الكبدى عن المتطوعين الآصحاء كما يزيد بصودة واضحة فى مرضى سرطان الكبد عن مرضى التليف الكبدى والمتطوعين الآصحاء.

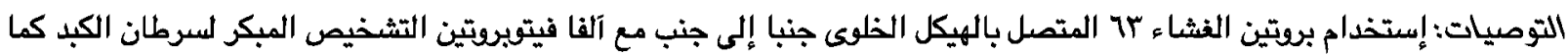

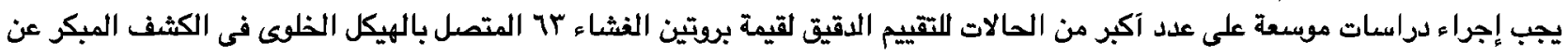
سرطان الكبد. 